\author{
ANNA JAKONIUK-Diallo \\ Uniwersytet im. Adama Mickiewicza \\ $w$ Poznaniu
}

\title{
MIEJSCE MUZYKOTERAPII W STYMULOWANIU ROZWOJU DZIECI Z NIEPEŁNOSPRAWNOŚCIĄ INTELEKTUALNĄ
}

\begin{abstract}
Jakoniuk-Diallo Anna, Miejsce muzykoterapii w stymulowaniu rozwoju dzieci z niepetnosprawnościa intelektualna [The Role of Music Therapy in the Stimulation of Development of Children with Developmental Disability]. Studia Edukacyjne nr 50, 2018, Poznań 2018, pp. 45-55. Adam Mickiewicz University Press. ISSN 1233-6688. DOI: 10.14746/se.2018.50.3

Music therapy is a complex process conducive to the improvement of the functioning of the organism subjected to this type of action. It is a multifaceted action including various forms and methods of working with the use of music. In this text I present an analysis of the importance of such activities for the development of children with intellectual disabilities and try to assess the extent to which such activities are used in working with this group of people. The analysis of the ways of performing music therapy in relation to children with intellectual disabilities is illustrated by the results of a diagnostic survey.
\end{abstract}

Key words: music therapy, disabled child, intellectual disability, rhythmic activities

\section{Wprowadzenie}

Muzyka jest stałym elementem naszego rozwoju. Stanowi źródło doświadczeń, związanych zarówno z ciałem, jak i umysłem, a jej wpływ na emocje jest bezpośredni. Poprzez swą wielowymiarowość muzyka trafia w swoisty sposób do każdego dziecka, jednak tym spośród nich, których rozwój jest zaburzony, a możliwości percepcyjne ograniczone lub ukryte, świat muzyki należy przybliżać1. Dzieci z niepełnosprawnością intelektualną stanowią taką grupę. Pomimo ograniczeń w procesach przetwarzania informacji i szeroko rozumia2012.

${ }^{1}$ A. Jakoniuk-Diallo, Percepcja stuchowa dzieci z niepetnosprawnościa intelektualna, Poznań 
nym uczeniu się, wykazują uzdolnienia muzyczne, a ich inteligencja muzyczna znajduje się nierzadko na wyższym poziomie niż inne kompetencje ${ }^{2}$. Zarówno indywidualne zajęcia muzykoterapeutyczne, jak i włączenie tego typu działań $\mathrm{w}$ proces edukacji, stwarzają okazję dla wspomagania ogólnego rozwoju wyżej wymienionej grupy dzieci. Mogą przy tym pełnić funkcję korekcyjno-kompensacyjną w sytuacji ograniczonego dostępu do bodźców i sprzyjać redukcji nadmiernego napięcia psychofizycznego. Podczas prowadzonych przeze mnie badań, to jest ewaluacji percepcji słuchowej dzieci z niepełnosprawnością intelektualną, interesujące wydało mi się to, jakie formy szeroko rozumianej muzykoterapii wykorzystywane są $\mathrm{w}$ procesie stymulowania rozwoju tej grupy osób. Dzieci mają w sobie naturalną wrażliwość na muzykę i zabiegi edukacyjno-terapeutyczne. Osoby z nimi pracujące mogą więc tę niezwykłą, naturalną dziecięcą wrażliwość rozwijać lub tłumić. Stereotypy, dotyczące możliwości percepcyjnych osób z niepełnosprawnością intelektualną, nierzadko decydują o tym, że prowadzone $\mathrm{z}$ nimi zajęcia muzyczne są realizowane $\mathrm{w}$ sposób rutynowy, nudny, uproszczony, a bywa, że osoby, które tego typu zajęcia prowadzą nie mają $w$ tym zakresie odpowiedniego wykształcenia ${ }^{3}$. Sytuacja taka przekłada się w bezpośredni sposób na jakość stymulacji muzycznej oraz uproszczenie celów, jakim owa stymulacja służy.

\section{Cele muzykoterapii a stymulowanie rozwoju dzieci z niepełnosprawnością intelektualną}

Jak podkreśla L. Konieczna-Nowak ${ }^{4}$, muzyka zawsze odgrywa w naszym życiu rolę terapeutyczną, pozwala uzyskiwać równowagę pomiędzy przeżyciami emocjonalnymi a fizjologicznymi, poprawiając tym samym stan funkcjonowania układu nerwowego. Za nadrzędny jej cel można więc uznać homeostazę organizmu, osiąganą na bazie doświadczeń emocjonalnych i poznawczych. Pozostałe cele zajęć muzykoterapeutycznych są związane z szeregiem funkcji, jakie mogą one pełnić. Funkcja emocjonalna odpowiada więc za dotarcie do pozytywnych przeżyć i w konsekwencji poprawę nastroju jednostki, co przekłada się na ćwiczenie zaburzonych funkcji psychofizycznych. Funkcja poznawcza pozwala na realizację celów, związanych z koncentracją uwagi słuchowej, rozwijaniem pamięci słuchowej, analizą i syntezą informacji słuchowej. Funkcja ekspresyjna wiąże się ze stworzeniem warunków do

\footnotetext{
2 P. Nordoff, C. Robbins, Terapia muzyką w pracy z dziećmi niepetnosprawnymi, Kraków 2008.

${ }^{3}$ A. Jarkowska, Muzyka jako element wychowania w rozwoju osobowym dziecka z niepetnosprawnością, Tychy 2014.

${ }^{4}$ L. Konieczna-Nowak, Wprowadzenie do muzykoterapii, Kraków 20013.
} 
ujawniania uczuć, poprzez grę na instrumentach i śpiew. Funkcja wyobrażeniowo-odreagowująca służy realizacji celu, jakim jest zwiększenie procesów wyobrażeniowych u osoby poddawanej muzykoterapii. Funkcja komunikatywna związana jest z nauką porozumiewania się oraz nabywaniem zachowań społecznych z tego zakresu.

W pracy z dziećmi niepełnosprawnymi na uwagę zasługują ponadto te cele - rewalidacyjne i profilaktyczne - które są obecne na gruncie szeroko rozumianej pedagogiki specjalnej. Służą one stymulowaniu rozwoju poznawczego, budowaniu pozytywnego stosunku do siebie, rozwijaniu kompetencji komunikacyjnej oraz zachowań prospołecznych. Funkcją istotną tego typu zajęć jest też pobudzanie zainteresowań muzycznych, wrażliwości muzycznej oraz aktywności inspirowanej muzyką. Cele te są jeszcze bardziej uszczegółowione, jeżeli uwzględnimy fakt niepełnosprawności intelektualnej dziecka. Wówczas, zajęcia muzykoterapeutyczne służą poprawie koordynacji słuchowo-ruchowej oraz wzrokowo-słuchowo-ruchowej, doskonaleniu orientacji w schemacie własnego ciała oraz orientacji przestrzennej, poprawie integracji sensorycznej, stymulowaniu pracy obu półkul mózgu, rozwijaniu umiejętności naśladownictwa, stymulowaniu rozwoju mowy, w tym umiejętności artykulacyjnych, odreagowywaniu napięć emocjonalnych, rozwijaniu wrażliwości emocjonalnej, umiejętności muzykowania oraz kreatywności.

Realizacja wyżej wymienionych celów może sprzyjać i służyć bezpośrednio stymulowaniu rozwoju dzieci z niepełnosprawnością intelektualną wówczas, kiedy muzykoterapia jest profesjonalnym, zawodowym działaniem ${ }^{5}$. Oznacza to, że osoba podejmująca tego typu aktywność powinna legitymizować się nie tylko wykształceniem muzycznym, ale i pedagogicznym, najlepiej z zakresu pedagogiki specjalnej. Badania realizowane przeze mnie w latach 2010-2012 wskazywały, iż w tej sferze istnieją zdecydowane braki. Zajęcia muzykoterapeutyczne $\mathrm{z}$ dziećmi z niepełnosprawnością intelektualną realizowały, w tym czasie, między innymi osoby nie posiadające żadnej wyżej wymienionej kategorii wykształcenia. Można by sądzić, że receptywny odbiór muzyki przez dzieci z niepełnosprawnością intelektualną nie wymaga od osoby wykorzystującej tego typu środek w działaniach edukacyjnych, czy szeroko rozumianym wspomaganiu rozwoju, specjalnych kompetencji. Wszak osoby poddawane tego typu oddziaływaniom tylko słuchają muzyki. Okazuje się jednak, że nawet ten rodzaj oddziaływania muzyką wymaga profesjonalnego przygotowania. W przeciwnym razie mamy do czynienia z sytuacją, w której nawet receptywny odbiór utworu nie przynosi zamierzonych korzyścíi

5 Tamże.

${ }^{6}$ A. Jakoniuk-Diallo, Wykorzystanie muzyki w dynamizowaniu potencjałów rozwojowych dzieci z niepetnosprawnościa, [w:] Stymulowanie potencjatu twórczego osób z różnymi potrzebami edukacyjnymi, red. E. Lubińska-Kościółek, K. Plutecka, Kraków 2011. 


\section{Warunki niezbędne dla realizacji muzykoterapii receptywnej i ekspresywnej}

Muzykoterapia receptywna, wykorzystywana jeszcze do niedawna na gruncie neurologii, psychiatrii i psychologii klinicznej, jest współcześnie istotną formą terapii pedagogicznej w odniesieniu do dzieci z zaburzeniami rozwoju ${ }^{7}$. Oczywiście, w najprostszej postaci wiąże się z udziałem słuchacza w różnych formach, w których muzyka eksponowana jest w jakiejś złożonej, przemyślanej formie, takiej jak słuchowisko, koncert, przedstawienie operowe. Działania te służą wywołaniu u słuchacza pozytywnych przeżyć estetycznych. Muzykoterapia receptywna może realizować jednak głębsze cele, stymulując zarówno procesy poznawcze, jak i emocjonalno-motywacyjne wówczas, gdy objęta jest nią dana osoba. Z uwagi na fakt, że percepcja muzyki u każdego z nas przebiega nieco inaczej, dla realizacji wyżej wymienionych celów niezbędna jest indywidualizacja procesu muzykoterapii. Działania receptywne wymagają więc indywidualnego doboru utworów, a nierzadko również posługiwania się idiomami muzycznymi, co może uczynić jedynie muzyk-improwizator ${ }^{8}$. W pracy z dziećmi z niepełnosprawnością intelektualną muzykoterapia receptywna może odgrywać rolę istotną z uwagi na fakt, że tę grupę osób charakteryzują, jak podkreślają P. Nordoff i C. Robbins, liczne nieuświadomione konflikty i zahamowania. Najbardziej istotny wydaje się w tej sytuacji dobór tak zwanej muzyki programowanej, która ma na celu pomóc dziecku uzewnętrznić emocje aktualne lub te zalegające, związane z konfliktem, który miał miejsce w przeszłości lub obecnie.

Z kolei muzykoterapia ekspresywna (aktywna), oparta na technikach improwizacji dowolnej, takich jak śpiew, gra na instrumentach, ruch przy muzyce oraz działania twórcze z wykorzystaniem elementów muzycznych i działania korekcyjne z wykorzystaniem takich elementów, stymuluje szereg procesów zachodzących w układzie nerwowym słuchacza. W pracy terapeutycznej z dziećmi niepełnosprawnymi, najczęściej wykorzystywaną formą muzykoterapii aktywnej są zajęcia ruchowo-rytmiczne. Rytm, jak podkreśla A. Jarkowska ${ }^{9}$, ma spontaniczny dostęp do umysłu każdego dziecka, nawet tego, które wykazuje trudności w myśleniu logicznym, a przy tym brak zdolności muzycznych. Zajęcia rytmiczno-ruchowe powinny zatem uwzględniać aktualny nastrój dziecka, jego stan psychofizyczny. W zajęciach tego typu należy przechodzić od form prostych, typu klaskanie, tupanie, do coraz bardziej złożonych, w sytuacji osiągania przez dziecko swobody ruchowej. M. Ra-

\footnotetext{
7 T. Stegemann, Arteterapie dla dzieci i młodzieży, Gdańsk 2015.

8 P. Nordoff, C. Robbins, Terapia muzyka.

9 A. Jarkowska, Muzyka jako element wychowania.
} 
szewska ${ }^{10}$ zwraca uwagę także na inne formy zajęć muzykoterapeutycznych, istotne w stymulowaniu rozwoju dzieci z niepełnosprawnością intelektualną, między innymi improwizację instrumentalną lub wokalną. To muzykoterapeuta inspiruje tego typu improwizację, przy czym po stronie dziecka może być ona zarówno spontaniczna, jak i ukierunkowana, może służyć komunikacji pozawerbalnej, budowaniu " ja” w relacji z innymi, a także stymulacji sensorycznej i aktywności poznawczej.

Kolejną istotną formą realizacji muzykoterapii aktywnej jest wykonywanie/odtwarzanie utworów muzycznych. Tego rodzaju zajęcia terapeutyczne służą poprawie koncentracji uwagi, koordynacji słuchowo-wzrokowo-ruchowej, rozwojowi empatii i umiejętności współdziałania. W przypadku dzieci z niepełnosprawnością intelektualną, ta forma realizacji aktywnej terapii muzyką przyjmuje często postać śpiewu. Taki rodzaj terapii służy kształtowaniu ekspresji werbalnej, skorygowaniu mowy i wymowy, odreagowaniu napięcia. Śpiew może pełnić również funkcję diagnostyczną, wówczas gdy terapeuta na jego podstawie określa stan emocjonalny dziecka i zaburzenia $\mathrm{w}$ zakresie posługiwania się przez nie dźwiękiem. Formą przygotowującą dzieci z niepełnosprawnością intelektualną do śpiewu jest mowa rytmizowana. Mowę taką charakteryzują zmiany tempa i natężenia oraz akcentowanie wybranych sylab. Taki sposób mówienia pozostawia dzieciom możliwość pewnej improwizacji.

Szczególne znaczenie w muzykoterapeutycznej pracy ekspresywnej z dziećmi z niepełnosprawnością ma także wspólna improwizacja na instrumentach. Pozwala ona nie tylko na poprawę koncentracji dziecięcej uwagi oraz koordynacji wzrokowo-ruchowej i słuchowo-ruchowej, lecz także na rozwój wyobraźni. Harmonia, melodia i rytm stanowią te elementy improwizacji, które są przez dzieci powtarzane, a następnie przetwarzane, by w konsekwencji zostały rozwinięte. Dzięki tego typu zajęciom dzieci uczą się stopniowo rozpoznawać strukturę muzyczną, to jest przewidują zmianę tempa, dynamiki, oczekują na kadencję. Sytuacja improwizacji na instrumentach może także pełnić funkcję diagnostyczną, bowiem zaburzenia dziecięcego rozwoju znajdują swoje odbicie w sposobie gry na instrumentach. Można to zaobserwować podczas improwizacji instrumentalnej, nawet tej z użyciem tak prostego instrumentu jak bębenek. Gra niektórych dzieci jest schematyczna, jakby mechaniczna (pozbawiona muzykalności). Inne, w sposób kompulsywny trzymają się jednego pulsu, nie dostosowując gry do improwizacji. Jeszcze inne grają w sposób chaotyczny, nieuporządkowany. Zdarzają się też sytuacje, kiedy dzieci, których funkcjonowanie charakteryzuje spowolnienie psychoruchowe, podczas gry na instrumencie ożywiają się i ujawniają swo-

${ }^{10}$ M. Raszewska, W. Kuleczka, Muzyka otwiera nam świat, Gdańsk 2009. 
je emocje. Tego typu obserwacje, odnoszące się do specyfiki funkcjonowania poszczególnych dzieci, poddawanych muzykoterapii ekspresywnej, mogą stanowić istotny fragment diagnozy klinicznej: negatywnej oraz pozytywnej, tak ważnych dla wspomagania rozwoju dzieci z niepełnosprawnością intelektualną. Ewaluacja zachowań dzieci może przy tym następować zarówno podczas muzykoterapii indywidualnej, jak i grupowej. W jednym i drugim przypadku o jakości obserwacji dzieci, jak i skuteczności działań terapeutycznych decyduje profesjonalne przygotowanie muzyczne i pedagogiczne osoby prowadzącej zajęcia. Z tego względu, wykształcenie muzykoterapeuty jawi się ponownie jako kluczowy warunek jakości jego pracy z dziećmi z niepełnosprawnością, w tym czynnik decydujący o wyborze metod oraz form pracy terapeutycznej.

\section{Metody i formy muzykoterapii wykorzystywane w stymulowaniu rozwoju dzieci niepełnosprawnością intelektualną}

Istnieją dwie podstawowe formy muzykoterapii - indywidualna oraz grupowa. Każda z nich ma oczywiście swoje walory. Pierwsza, pozwala na dostosowanie działań terapeutycznych do potrzeb dziecka w danej chwili i sprzyja nawiązaniu z nim wyjątkowej więzi. Druga, pozwala poczuć się każdemu z dzieci członkiem grupy, a zatem umożliwia odczuwanie interpersonalnej więzi, przy jednoczesnym zaprezentowaniu przed innymi swojej odrębności, na przykład podczas improwizacji na instrumentach, czy improwizacji ruchowych.

$\mathrm{W}$ pracy z dziećmi z niepełnosprawnością intelektualną terapeuta muzyczny staje zarówno przed koniecznością wyboru jednej ze wspomnianych form pracy, jak i przed jej indywidualizacją, a nierzadko koniecznością modyfikacji samej metody pracy. Dzieje się tak, ponieważ dzieci rozwijające się w sposób prawidłowy, przy odpowiedniej motywacji, potrafią współpracować, realizując zadania nawet wówczas, kiedy te przekraczają ich możliwości. Z kolei dzieci z niepełnosprawnością intelektualną czasem nie wykazują zainteresowania tym, co dzieje się wokół nich, a bywa i tak, że szybko zniechęcają się do realizacji proponowanych działań. Nieudolne działanie muzykoterapeutyczne może więc potencjalnie spowodować, że dziecko z niepełnosprawnością intelektualną trudno będzie zachęcić do tego typu aktywności, stąd tak istotna jest forma oddziaływań. Z myślą o dzieciach z niepełnosprawnością intelektualną M. Raszewska i W. Kuleczka ${ }^{11}$ zaproponowały program od-

\footnotetext{
11 Tamże.
} 
działywań muzykoterapeutycznych, uwzględniający potrzeby poznawcze tej grupy dzieci oraz ich ograniczenia, między innymi w zakresie koncentracji uwagi.

Program zaproponowany przez wyżej wymienione autorki uwzględnia następujące formy:

- Ruch przy muzyce:

- opowieści muzyczne,

- zabawy ze śpiewem,

- zabawy oddechowe,

- zabawy ruchowe naprzemienne, koordynujące pracę półkul mózgowych;

- Gra na instrumentach perkusyjnych i niekonwencjonalnych, wykonanych przez dzieci;

- Podejmowanie prób śpiewu;

- Podejmowanie prób własnej ekspresji improwizacji.

Nieprzypadkowo M. Raszewska oraz W. Kuleczka'² akcentują fakt podejmowania przez dzieci prób, które nie obligują ich samych oraz terapeuty do kontynuacji aktywności. Dla dalszego przebiegu zajęć kluczowa jest tu motywacja samego dziecka z niepełnosprawnością intelektualną.

Wśród metod muzykoterapeutycznych, które w swoim programie zaproponowały wyżej wymienione autorki znalazły się:

- gimnastyka twórcza Rudolfa Labana;

- gimnastyka twórcza Carla Orffa;

- warsztaty ruchu twórczego Giny Levete.

Dodatkowo w programie zaproponowanym dla dzieci z niepełnosprawnością intelektualną znalazły się wzbogacone o podkład muzyczny metody, zaczerpnięte z pedagogiki specjalnej, takie jak:

- Kinezjologia Edukacyjna Paula Dennisona;

- Metoda Ruchu Rozwijającego;

- Metoda Dobrego Startu;

- Metoda Felicji Affolter.

Powyższe formy i metody stanowią, oczywiście, jedynie pewną propozycję, z której doświadczony muzykoterapeuta może korzystać w całości bądź w części. W jednym i drugim przypadku obowiązuje go zasada stopniowania trudności - uwzględnienie działań bliższych doświadczeniom muzycznym dziecka z niepełnosprawnością intelektualną i tych, które są dla niego łatwiejsze w zakresie realizacji. Obydwa wymienione kryteria spełnia metoda Carla Orffa. Twórca w poszukiwaniu działań wprowadzających dziecko w świat muzyki połączył w całość ruch, śpiew oraz grę na instrumentach, określa-

12 Tamże. 
jąc swą metodę muzyką elementarną. Prostota instrumentów jest w wyżej wymienionej metodzie jej ważnym aspektem, uwzględniającym możliwości motoryczne oraz percepcyjne osób z niepełnosprawnością intelektualną. Bez specjalistycznego przygotowania mogą one grać bowiem na takich instrumentach melodycznych, jak: ksylofony i dzwonki oraz na instrumentach niemelodycznych, jak: bębenki, marakasy, kastaniety, trójkąty, kołatki i talerze. Układ melodyczno-niemelodyczny pozwala dzieciom z niepełnosprawnością intelektualną nie tylko na doświadczanie sprawstwa w obszarze samodzielnego muzykowania, ale także na doświadczanie zróżnicowanej barwy oraz rytmu, co jest istotne przy akompaniamencie tańców, piosenek, czy ilustracji muzycznej bajek oraz opowieści. Współczesna wersja metody C. Orffa na grunt pedagogiki specjalnej zaimplikowana została jako zmodyfikowana terapia wielosensoryczna Gertrudy Orff, a jej adresatami są dzieci z niepełnosprawnością intelektualną, niesłyszące oraz niewidome.

Drugą, najczęściej wykorzystywaną w pracy muzykoterapeutycznej z dziećmi z niepełnosprawnością metodą jest rytmika ruchowa Emila J. Dalcroze' $^{13}$. Instrumentarium perkusyjne wzbogacone jest przez naturalne efekty głosowe dzieci, takie jak: gwizdy, świsty, pomruki, kląskanie, szuranie oraz pstrykanie. Muzykowanie, w świetle takiego instrumentarium jest aktywnością dostępną wszystkim dzieciom. Sama rytmika w tej metodzie obejmuje: ćwiczenia słuchowe, improwizowanie ruchu, marsze, podskoki oraz tańce. Forma jest tu zawsze dostosowana do indywidualnych potrzeb dziecka, jego osobowości. Jest to zasada obowiązująca przy realizacji jakichkolwiek zajęć muzykoterapeutycznych dla dzieci z niepełnosprawnością intelektualną. Mimo to, początki zajęć bywają trudne, w kontekście lęku dzieci i nieprzewidywalności ich zachowań. $W$ takiej sytuacji dostosowanie metody do indywidualnych potrzeb psychicznych i edukacyjnych dziecka pozwala mu aktywnie włączyć się w zajęcia, zachęca do eksperymentowania z dźwiękiem, pozwala na radość doświadczania muzyki i jej inscenizacji, poprzez ruch ciała. Niejednokrotnie, udział dzieci z niepełnosprawnością intelektualną $\mathrm{w}$ zajęciach muzykoterapeutycznych zależy od umiejętności posługiwania się przez terapeutę idiomem muzycznym. Kompetencje takie są udziałem muzyków, wykształconych w zakresie improwizacji instrumentalnej. Niezależnie od wyboru metody muzykoterapii, w pracy z dziećmi z niepełnosprawnością intelektualną, jak podkreślają P. Nordoff i C. Robbins ${ }^{14}$, istotna jest bezwarunkowa akceptacja dziecka, wraz ze wszystkimi jego ograniczeniami, podchwytywanie i podtrzymywanie dziecięcych zachowań autoterapeutycznych, poszanowanie spontaniczności dziecięcych

${ }^{13}$ K. Stachyra (red.), Podstawy muzykoterapii, Lublin 2012.

${ }^{14}$ P. Nordoff, C. Robbins, Terapia muzyka. 
działań muzycznych, tolerancja dla niedoskonałego wykonywania przez dziecko ćwiczeń oraz umożliwienie dokonywania wyboru instrumentów, rodzaju i kolejności aktywności muzycznej oraz stworzenie warunków dla odnoszenia przez dziecko sukcesów.

\section{Wyniki sondażu diagnostycznego}

W kontekście zrealizowanej przeze mnie ewaluacji poziomu percepcji słuchowej dzieci z niepełnosprawnością intelektualną ${ }^{15}$, za istotną uznałam realizację sondażu dotyczącego rodzaju zajęć muzykoterapeutycznych, oferowanych wyżej wymienionej grupie dzieci, jak i przygotowania merytorycznego osób zajmujących się muzykoterapią na terenie placówek oświatowych Poznania, Konina, Koła oraz Kalisza, do których uczęszczają dzieci z niepełnosprawnością intelektualną lub dzieci z zaburzeniami rozwoju, zagrożone tą niepełnosprawnością. Badaniami objęto 14 szkół specjalnych, 20 przedszkoli specjalnych, 14 szkół ogólnodostępnych z oddziałami integracyjnymi oraz 20 przedszkoli integracyjnych, 10 żłobków integracyjnych.

Z badań (analiza dokumentów) wynika, iż największa liczba zajęć muzykoterapeutycznych dla dzieci z niepełnosprawnością intelektualną realizowana jest $\mathrm{w}$ przedszkolach specjalnych (100\% badanych placówek) oraz szkołach specjalnych (70\% szkół) i przedszkolach integracyjnych (50\% przedszkoli). Jednocześnie, brakuje tego typu zajęć w żłobkach integracyjnych i szkołach z oddziałami integracyjnymi. Tutaj realizowane są zajęcia rytmi$\mathrm{ki}$, jednakże nie są one tożsame z muzykoterapią. Zajęcia z muzykoterapii nie są realizowane także na terenie poradni psychologiczno-pedagogicznych, w których konsultowane są dzieci z niepełnosprawnością intelektualną, pomimo że inne formy terapii, na przykład zajęcia z socjoterapii dla wymienionej grupy osób są tam prowadzone.

$\mathrm{W}$ przedszkolach specjalnych zajęcia muzykoterapeutyczne realizowane są 2-3 razy w tygodniu, podczas gdy w szkołach specjalnych i przedszkolach integracyjnych już tylko raz $\mathrm{w}$ tygodniu. Zarówno w placówkach specjalnych, jak i ogólnodostępnych dominującą formą jest muzykoterapia receptywna, rzadziej ekspresywna. Do metod najczęściej wykorzystywanych w placówkach specjalnych należą: trening Jacobsona, metoda M. i Ch. Knill oraz zmodyfikowana wersja metody C. Orfa. Do metod najczęściej wykorzystywanych $\mathrm{w}$ placówkach integracyjnych lub z oddziałami integracyjnymi należy: neuromuzykoterapia, metoda Batti Straus oraz muzykoterapia improwizacyjna.

${ }^{15}$ Por. A. Jakoniuk-Diallo, Percepcja stuchowa dzieci. 
Wyniki sondażu wskazują, że największą grupę muzykoterapeutów stanowią osoby legitymujące się wykształceniem wyższym z zakresu edukacji artystycznej; cztery osoby prowadzące zajęcia w przedszkolach specjalnych posiadały wykształcenie z zakresu pedagogiki specjalnej i brak przygotowania w zakresie muzyki, czy muzykoterapii, natomiast dwie osoby, spośród prowadzących zajęcia w przedszkolach integracyjnych, posiadały studia podyplomowe z zakresu muzykoterapii.

Oczywiście, przytoczone wyniki sondażu nie pozwalają na daleko idące uogólnienia, jednak stanowią pewną ilustrację podjętego tematu. Na uwagę zasługuje fakt braku rozpowszechnienia zajęć muzykoterapeutycznych we wszystkich placówkach oświatowych, do których uczęszczają dzieci z niepełnosprawnością intelektualną. Braki w tym zakresie dotykają, niestety, żłobków integracyjnych, sprawujących opiekę nad małymi dziećmi zagrożonymi niepełnosprawnością, co świadczy o ograniczeniu działań tych placówek w zakresie wczesnego wspomagania rozwoju. Ponadto, muzykoterapia nie jest uwzględniana w programie wszystkich przedszkoli integracyjnych, a jedynie w niektórych zajmuje należne jej miejsce. W pozostałych, jak i w szkołach ogólnodostępnych z oddziałami integracyjnymi, zajęcia muzykoterapii zastąpione zostają zajęciami rytmiki, z którymi są utożsamiane. Sytuacja taka stawia jednak pod znakiem zapytania nie tylko zaspokojenie specjalnych potrzeb edukacyjnych dzieci z niepełnosprawnością intelektualną, ale ich szeroko rozumianych potrzeb rozwojowych, to jest stymulacji neurorozwoju, rozwoju poznawczego i społeczno-emocjonalnego. O ograniczonym wykorzystaniu zajęć muzykoterapeutycznych w odniesieniu do dzieci z niepełnosprawnością intelektualną zdaje się przesądzać brak właściwego przygotowania merytorycznego kadry, realizującej tego typu zajęcia. Łączenie przez muzykoterapeutów kompetencji z zakresu pedagogiki specjalnej i instrumentalistyki jest rzadkością. Wątpliwości, w świetle powyższego, dotyczą samego kształcenia specjalnego. Od czasu, kiedy studia z zakresu pedagogiki specjalnej przestały mieć charakter jednolitych, pięcioletnich, z programu usunięto obligatoryjne kształcenie w dziedzinie terapii muzyką. Niedostateczny stopień wykorzystania muzykoterapii w stymulowaniu rozwoju dzieci z niepełnosprawnością intelektualną jest niewątpliwie pokłosiem wyżej wymienionych czynników. Postulowane zmiany w tym zakresie należy rozpocząć z pewnością od przygotowania pedagogów, w tym studentów tego kierunku, do działań w zakresie muzykoterapii. Kolejnym krokiem jest kształcenie aktywnych zawodowo pedagogów specjalnych w dziedzinie metod muzykoterapeutycznych, to znaczy organizowanie szkoleń, studiów podyplomowych i tym podobnych. Równoległe działania powinny dotyczyć zwiększania środków na finansowanie terapii muzyką w placówkach oświatowych. 


\section{BIBLIOGRAFIA}

Jakoniuk-Diallo A., Wykorzystanie muzyki w dynamizowaniu potencjałów rozwojowych dzieci z niepetnosprawnościa, [w:] Stymulowanie potencjału twórczego osób z różnymi potrzebami edukacyjnymi, red. E. Lubińska-Kościółek, K. Plutecka, Oficyna Wydawnicza Impuls, Kraków 2011.

Jakoniuk-Diallo A., Percepcja stuchowa dzieci z niepetnosprawnościa intelektualna, Wydawnictwo Naukowe UAM, Poznań 2012.

Jarkowska A., Muzyka jako element wychowania w rozwoju osobowym dziecka z niepetnosprawnościa, Wydawnictwo Maternus Media, Tychy 2014.

Konieczna-Nowak L., Wprowadzenie do muzykoterapii, Oficyna Wydawnicza Impuls, Kraków 2013.

Nordoff P., Robbins C., Terapia muzyka w pracy z dziećmi niepetnosprawnymi, Oficyna Wydawnicza Impuls, Kraków 2008.

Raszewska M., Kuleczka W., Muzyka otwiera nam świat, Wydawnictwo Harmonia, Gdańsk 2009.

Stachyra K. (red.), Podstawy muzykoterapii, Wydawnictwo UMCS, Lublin 2012.

Stegemann T., Arteterapie dla dzieci i młodzieży, Wydawnictwo Harmonia, Gdańsk 2015. 